\title{
国界线和行政区线表示南海 $\mathbf{U}$ 形海疆线的地图
}

唐丹玲 ${ }^{1,2^{*}}$, 刘宇鹏 ${ }^{1,2}$, 郝晓光 ${ }^{3}$, 吴常霞 ${ }^{1,4}$, 王素芬 ${ }^{1,2}$, 殷宇威 ${ }^{1,2}$

1. 中国科学院南海海洋研究所, 广东省海洋遥感重点实验室, 热带海洋环境国家重点实验室, 广州 510301;

2. 中国科学院大学, 北京 100049 ;

3. 中国科学院测量与地球物理研究所, 武汉 430077 ;

4. Marine Management, Dalhousie University, Halifax B3H 4R2, Canada

*联系人, E-mail: lingzistdl@126.com

2017-07-28 收稿, 2017-11-18 修回, 2017-11-20 接受, 2018-03-15 网络版发表

21 世纪海上丝绸之路协同创新中心海洋环境科学重大项目(2015HS05)、国家自然科学基金重点项目(41430968)、广东省科技厅项目 (2017B030301005)和广东国际战略研究院暨教育部战略基地 2017 年度重大研究课题资助

摘要 1951 年 4 月出版的以连续国界线画法绘制的我国南海 U 形海疆国界线的《中华人民共和国新地图》, 是佐 证中国南海疆界线的重要史料。研究发现, 该图用明确的连续国界线地图符号 $(\cdot><<>><<$ ) ( 当时国界线画 法)绘制标明了我国南海 U 形疆界线; 并用表示行政区划线的红色实线叠加描绘连续 $\mathrm{U}$ 形线, 将中国南海划在中 南行政区管辖范围内; 该地图的 U 形海疆国界线内包括东沙群岛、西沙群岛、南沙群岛、中沙群岛、台湾岛、北 部湾和曾母暗沙等. 该地图由光华与地学社编制、三联书店出版。研究提出, U 形海疆线是中国南海的海疆国界线, 主权归属中国; “连续U 形线”和“断续U 形线”两种方法都是国际认可的中国海疆国界线的描绘方式; 提议用“南海 $\mathrm{U}$ 形海疆线”更形象、准确、完整、科学地表征中国南海的海疆线.

关键词中国南海, 连续国界线, 1951 年, 行政区划线, 南海 U 形海疆线

地图作为国际上确认领土的一种证据，有利用 地图本身特有的功能来反映这条界线的形成与发 展过程的重要作用 ${ }^{[1]}$. 随着测绘技术的提高, 国际 法庭越来越倾向于赋予地图重要效力 ${ }^{[2]}$. 历史绘制 的U形线(U形疆界线)地图对我国南海主权有很高 的证明价值 ${ }^{[3]}$. 因此, 发现并研究U形海疆线相关 历史地图是清楚认识和证明我国南海海疆国界线 的关键手段.

大量明清以来官方和民间出版的版图、地图 册、地理学著作表明, 中国用地图疆界线段表达疆 界主张, 是古今通用的一种做法, 早在南海断续国 界线公布之前, 官方出版的地图册中就已存在对陆 地与海洋疆界线标示的画法 ${ }^{[4]}$. 由于早期地图绘制 缺乏国际统一标准, 南海疆界问题引起学者广泛讨
论 $^{[5]}$, 如U形海疆线的“连续线”和“断续线”画法的 变化 ${ }^{[5,6]}$ 、海疆线国界线表示符号 ${ }^{[7,8]}$ 和相应 $\mathrm{U}$ 形海 疆线的归属权和管辖权 ${ }^{[9]}$. 我们亟需历史地图的证 明 ${ }^{[10]}$, 并研究U形线整体的历史演变 ${ }^{[11]}$.

1912年 ${ }^{[12]} 、 1927$ 年 $^{[11] 、 1936}$ 年 $^{[13]}$ 的中国南海 地图都出现了南海的“连续疆界线”标示, 1948年 ${ }^{[14]}$ 及其后出现的中国南海地图大都采用“断续线”绘 制南海疆界线. 关于U形海疆线的“连续线”和“断 续线”画法变化, 前期研究认为南海海疆国界线以 不连接的线段(断续线段)标注在图上, 海水是波动 的，以“线段”表示海域疆界符合实际，而且具有允 许船只无害通过之属性 ${ }^{[14]}$. 目前, 亟需对U形线画 法的历史变化进行系统研究，揭示“连续线”和“断 续线”的历史意义和现实作用. 
1912 年 ${ }^{[12]} 、 1927$ 年 $^{[11]} 、 1936$ 年 ${ }^{[13]}$ 的中国南海 地图都是以“实线”表示U形线. 明确以国界线符号 $(\cdot>-<>>C<)$ 表示U形海疆国界线是1948年“南 海诸岛位置图”, ${ }^{[14]}$, 现今的中国南海U形海疆线表 示符号则表示为点加工字型 $(\cdot|-| \cdot|-|)$. 有海洋法学 家则对历史U形线地图的符号表示的科学性提出质 疑 $^{[5]}$. 因此, 关于U形海疆线符号表示的质疑, 亟需 寻找更有力的具有明确国界线符号表示的历史地图 资料，分析国界线符号的历史绘制变化.

对中国南海U形线范围内主权归属, 中国已经 有很多研究从历史渊源视角进行了探讨 ${ }^{[4,15,16]}$; 发 现证明力强的历史地图, 并从地图角度出发研究南 海U形海疆国界线形成的历史方面, 还有待提高和 完善 ${ }^{[11,14]}$.

因此, 发现并利用重要U形线历史地图资料, 阐述其地图效力和属性, 并分析其历史演变, 对解 决南海问题的国际质疑、维护南海主权具有重大 意义.

本研究着重介绍了1951年出版的《中华人民共 和国新地图》, 该地图同时以连续国界线和行政区 划线两种绘线表示了我国南海U形海疆国界线. 阐 述该新发现的U形线地图的特性, 并通过与历史地 图的对比, 分析U形海疆国界线的历史演变, 探讨 不同时期 U形线 “断续线”和 “连续线”的画法.
由于存在多种称谓表征南海疆界线, 本研究提出统 一用“南海U形海疆线”表称中国南海海疆国界线的 建议, 具有重要意义.

\section{1 资料来源}

新发现的1951年的《中华人民共和国新地图》 来自于杨浪先生的收藏. 杨浪先生收藏了丰富的地 图集，后赠予郝晓光. 唐丹玲在调研中发现了1951 年出版的《中华人民共和国新地图》(图1)地图册, 仔细研究时发现地图册中第3 4页的《全国政区图》 的“南海诸岛图”(图2(b))绘制了我国南海U形疆界 线图, 而且是用连续实线并用国界线和行政区划线 绘制.

该《中华人民共和国新地图》是于1951年4月由 光华与地学社编制、中国图书发行公司三联书店出 版、新新印刷厂承印的第2 版地图册, 共印刷 8 万册. 第1版也是由光华与地学社编制、中国图书发行公司 三联书店于1950年1月出版. 1951年版地图册是利用 历史旧图修订绘制而成，是当时首部最完善的新中 国地图. 该地图册中绘制有全国政区图、重点市区 用地布局图和地形图. 全国地图采用亚尔勃斯投影, 比例尺为 $1: 18000000$; 分图部分采用多圆雉投影, 比例尺为 $1: 3000000$, 特大省区为 $1: 5000000$ 或 $1: 7500000$, 南海分图比例尺为 $1: 30000000^{[17]}$. 该图

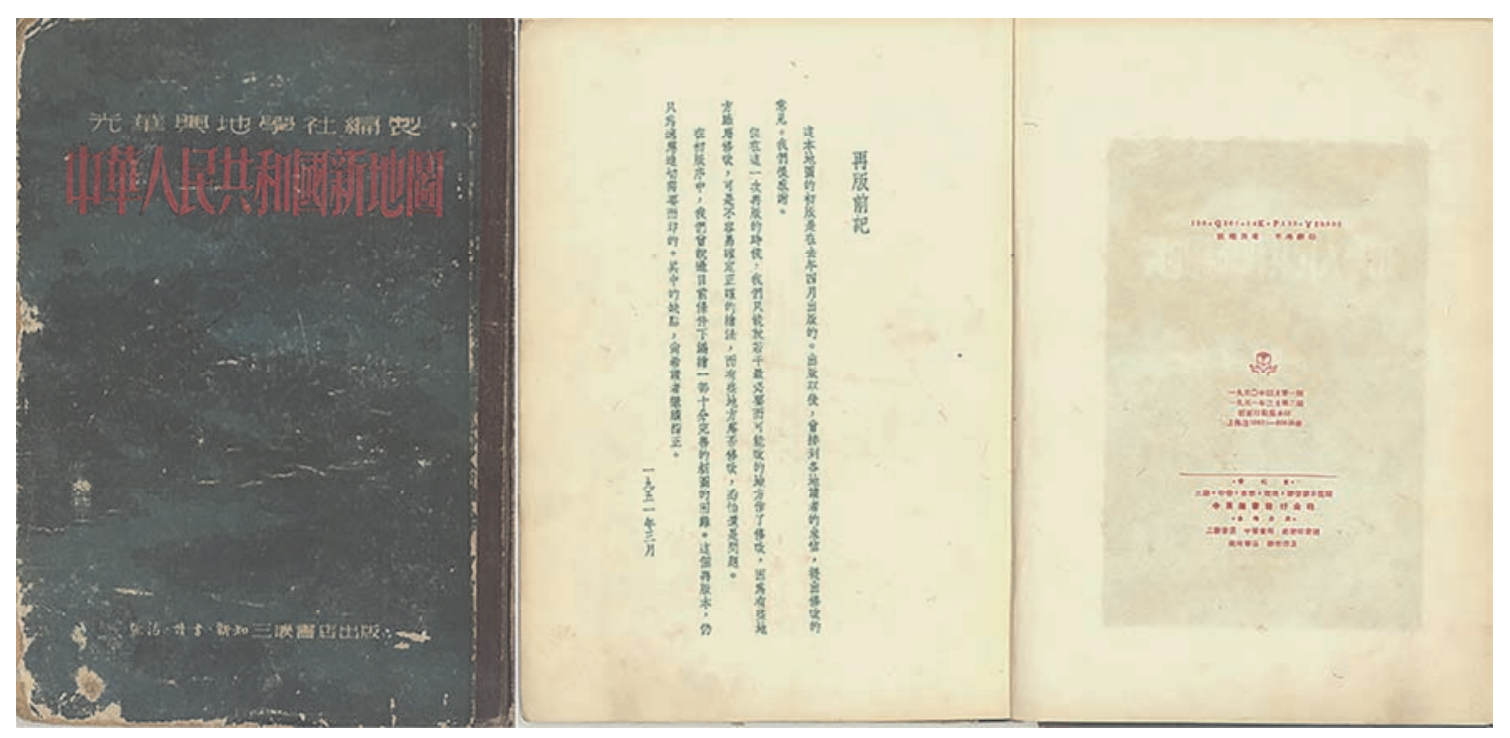

图 11951 年版《中华人民共和国新地图》封面与序

Figure 1 The cover and sequence of the New Map of the People's Republic of China in 1951 


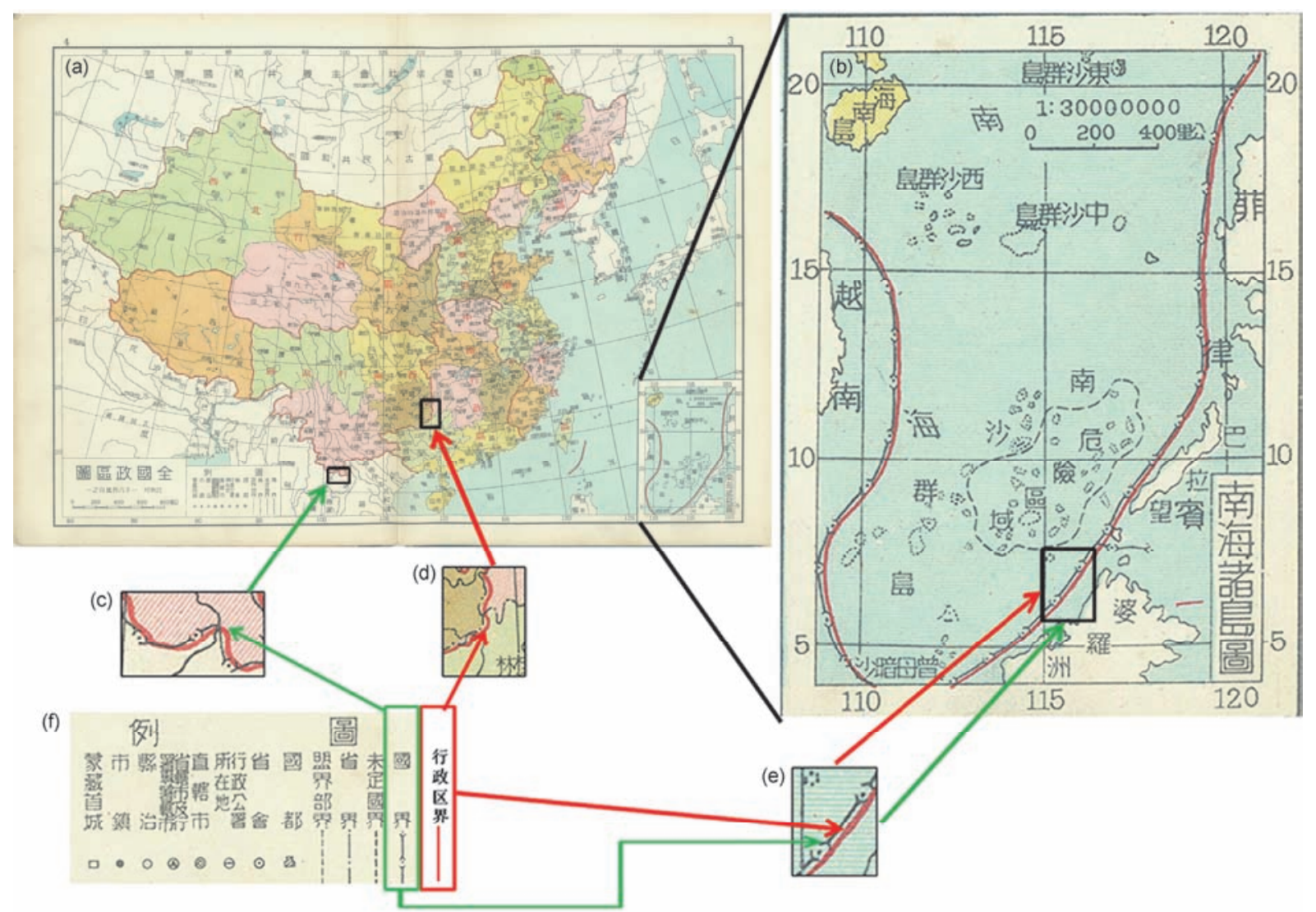

图 21951 年版《中华人民共和国新地图》. (a) 1951 年版《中华人民共和国新地图》中《全国政区图》; (b) 1951 年《全国政区图》的“南海 诸岛图”; (c) 全国政区图中截取的位于云南省边的国界图; (d) 全国政区图中截取的西南行政区和中南行政区的行政区界线图; (e) “南海诸岛 图”中截取的示意国界线和行政区线绘制的 U 形线图; (f) 全国政区图图例; 红色箭头指示行政区线, 绿色箭头指示国界线 ${ }^{[17]}$

Figure 21951 New Map of the People's Republic of China. (a) National Political Map in the 1951 New Map of the People's Republic of China; (b) the South China Sea map of the "National District Map" in 1951; (c) the "National Boundary Map" near Yunnan Province; (d) the southwest administrative district line; (e) south administrative district line map, and the U-line map drawing with boundaries and administrative lines; (f) illustration of the national district map. The red arrows indicate the administrative area line, the green arrows indicate the borderline ${ }^{[17]}$

册是在第 1 版地图基础上进行部分区域的修订，增 加五大行政区和若干行政省区的划分，比例尺和投 影方式沿用第1版.

1951年版《中华人民共和国新地图》第3 4页 收录的采用亚尔勃斯投影、比例尺为 $1: 18000000$ 的 《全国政区图》(图2(a))新增中国五大行政区、一个 中央行政区、一个自治区和西藏共八大区域的划分, 并以分色方式绘制各大省份, 用红色实线表示行政 区划线, 中国边界尤其是中国南海边界与相应国界 线位置完全一致且吻合.八大区域由北向南依次 是: 东北行政区、内蒙古自治区、中央直属华北区、 西北行政区、西藏、华东行政区、中南行政区和西 南行政区. 图中绘有各大水系, 并标明各大重点城 市名称. 该图册的右下角都绘有单独的南海分图.

\section{2 南海地图特征}

\section{1 描绘国界线的U形线}

1951年版地图中, 南海分图不仅采用连续明确 的国界线，而且采用连续U形行政区划线绘制了我 国南海疆界线. 该图的南海分图(图2(b)) 比例尺为 $1: 3000000$, 海洋采用蓝绿色表示. 该地图用与陆 地国界线相同的国界线符号 $(\cdot>-<>>-<\cdot)$ 绘制 $\mathrm{U}$ 形线，且整个U形线是以连续的国界线符号绘制， 国界线范围清晰明确.

\section{2 行政区划红线描述连续U形线}

1951年版地图南海分图在采用连续国界线地 图符号绘制U形线的同时，还采用标明行政区划线 
的红色连续实线对U形线进行描绘. 该地图红色连 续行政区划线的南海海域部分与U形国界线边界完 全吻合 (图2), 并与中南行政区的陆地行政区划线 相接, 明确表示中国南海U形线及其所属区域归属 中南行政区管辖范围.

\subsection{U形线边界范围}

地图中U形线边界范围(图2(b))包括：东沙群 岛、西沙群岛、中沙群岛、南沙群岛、台湾岛, 以 $4^{\circ} \mathrm{N}$ 曾母暗沙为最南国界线的中国南海海疆国界线. 地
图明确绘制了东沙群岛、西沙群岛、中沙群岛和南 沙群岛的主要岛屿和礁盘, 并明确标识四大群岛 名称.

\subsection{1年及之前的南海海疆图}

1936年白眉初根据《中国南海各岛屿图》编辑 出版的中学教科书《中华建设新图》中第2张图名 为《海疆南展后之中国全图》, 其南海疆界图用红 色实线绘制 ${ }^{[18]}$ (图3(a)). 图中在南海疆域内标有东 沙群岛、西沙群岛、南沙群岛和团沙群岛. 其四周 (a) 1936年

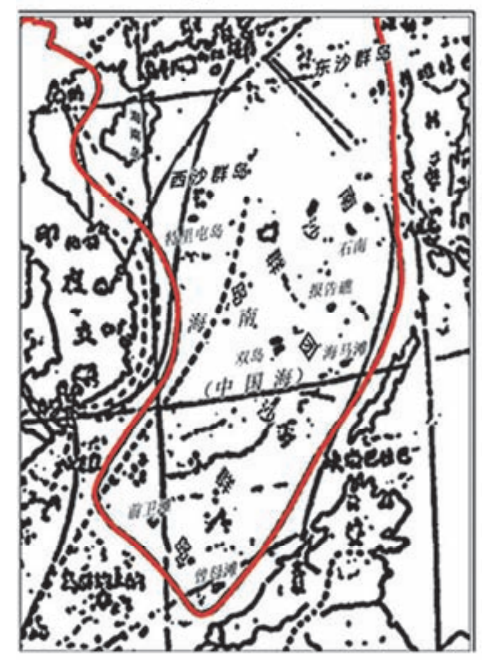

(b) 1948年

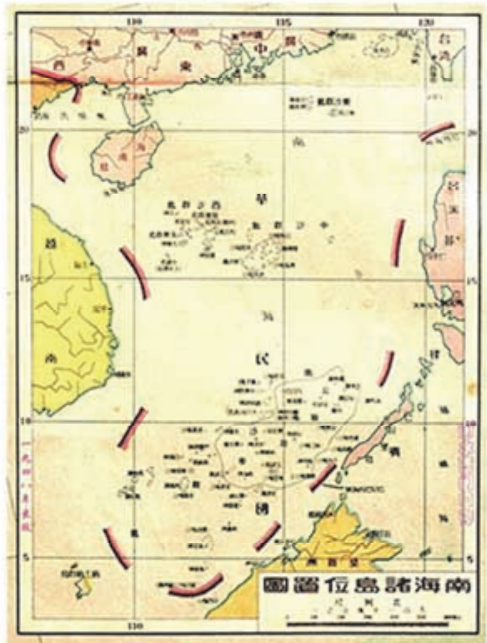

(c) 1948年

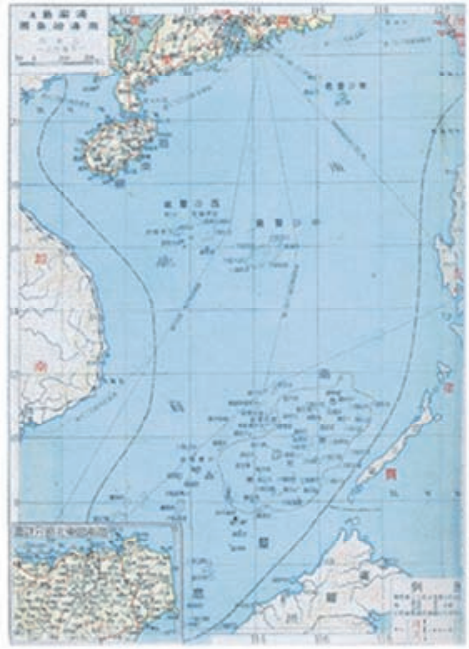

(d) 1951 年

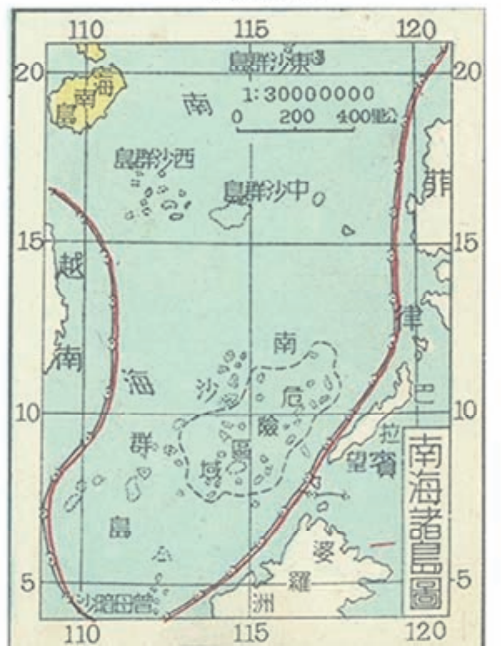

(e) 1951 年

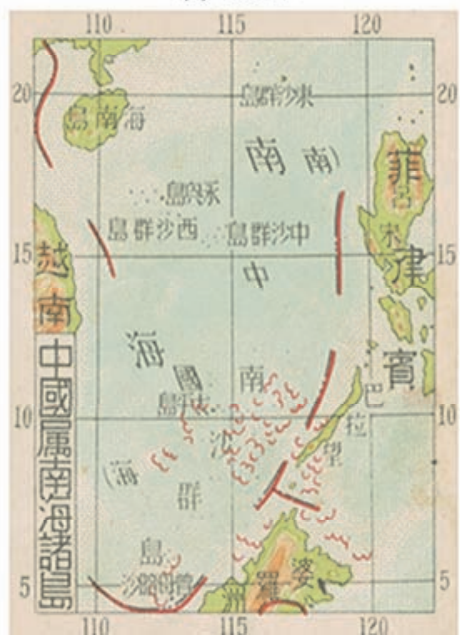

图 3 不同时期的南海疆界图. (a) 1936 年南海疆界图 ${ }^{[18]}$; (b) 1948 年民国内政部方域司编印的《南海诸岛位置图》 ${ }^{[19]}$; (c) 1948 年南海连续 U 形线图 ${ }^{[20]}$ (图编号 101); (d) 1951 年连续 U 形实线地图 ${ }^{[17]}$; (e) 1951 年中国南海诸岛分布图 ${ }^{[21]}$

Figure 3 The map of South China Sea border in different periods. (a) 1936 map of South China Sea border ${ }^{[18]}$; (b) Map of South China Sea Islands published by the Ministry of the Interior Division of The Republic of China $(1948)^{[19]}$; (c) map of South China Sea continuous U-boundary line $(1948)^{[20]}$; (d) map of consecutive U-shaped solid line (1951) ${ }^{[17]}$; (e) map of China's South China Sea islands $(1951)^{[21]}$ 
用国界线标明, 以示南海诸岛同属中国版图, 并确 认 $4^{\circ} \mathrm{N}$ 是最南国界线及对曾母暗沙的主权. 这是中 国地图上较早出现的南海传统疆域线 ${ }^{[22]}$.

《南海诸岛位置图》(图3(b)) 是由内政部方域司 编制, 傅角今主编, 1948年正式出版和公布的南海 地图. 该图于1946年10 12月在民国政府政务院批 准成立内政部方域司带领下测绘完成, 并于1947年 上半年由民国政府内政部方域司编绘、国防部测量 局代印《南海诸岛位置图》, 于1947年12月重新审 定，于1948年2月收人公开发行的《中华民国行政区 域图》中 ${ }^{[23]}$, 现南京第二档案馆存有原件 ${ }^{[14]}$. 该图 用十一段国界线构成的断续线, 西起中越边界北仑 河口, 东至台湾东北, 不仅标注东沙群岛、西沙群 岛、中沙群岛和南沙群岛的整体位置及名称, 而且 还标出曾母暗沙及大部分岛礁的个体名称 (图 $3(\mathrm{~b}))^{[4]}$. 此后官方和私人出版物均按照断续线的画 法在中国地图上标绘南海断续线 ${ }^{[24]}$, 许多国家出 版的地图均据此标绘中国疆域 ${ }^{[10]}$.

1948年亚光與地学社出版的中国南海的地图 (图3(c))沿袭了1948年《南海诸岛位置图》(图3(b)) U 形断续线的疆界, 但十一段线被完整的U形连续虚 线代替, 对中国南海的疆界线有更清晰的描绘 ${ }^{[20]}$.

本研究新发现的1951年4月由光华与地学社编 制的《中华人民共和国新地图》, 收录的《全国政 区图》的“南海诸岛图”以 $1: 3000000$ 比例尺用国界线 $(\cdot>-<\cdot>-<\cdot)$ 绘制了我国南海连续U形海疆国 界线, 并以红色连续实线标识的行政区划线再次描 绘U形线, 清楚表明U形线及其内海域归属中南行 政区管辖. 1947年中国政府在正式出版的权威性文 件中, 已明确这条边界线的最高级别——国界符 号” (与陆上国家间疆界线的画法一致 $)^{[11]}$. 光华与 地学社编制的该地图 ${ }^{[17]}$ 首次正式采用了连续的国 界线的画法, 印证了国家陆地国界线和海域国界线 画法一致, 并且很好地说明了在我国南海U形疆界 线确立之初, 就已经将南海纳人中南行政区的管辖 范围. 疆界线沿袭1948年《南海诸岛位置图》的U 形线地图范围. 这是目前发现的首张由连续U形国 界线和行政区线共同绘制的正式出版的中国南海 区域地图(图3(d)).

1951年世界與地学社出版的《中国属南海诸
岛》(图3(e))沿袭1948年U形断续线的疆界，采用断 续线画法 ${ }^{[21]}$. 本研究新发现的 1951年U形线地图 (图3(d))有吕宋海峡至台湾东岸区域U形线, 该图 (图3(e))有北部湾区域U形线, 该图与本研究新发现 地图相互补充.

\section{3 讨论}

\subsection{U形线的范围}

1948年《南海诸岛位置图》(图3(b)) 是于1946 年测绘完成, 1947 年编绘完成并印制《南海诸岛位 置图》 ${ }^{[23]}, 1947$ 年末审定, 于1948年正式向国际社 会宣布中国对南海及其附属岛屿的主权与管辖权 范围, 并确定了南海海疆国界线的位置, 线内标注 了“中华民国”字样 ${ }^{[25]}$. 该地图清楚表明的U形线西 起中越边界北仑河口, 东至台湾东北, 线内不仅标 注东沙群岛、西沙群岛、中沙群岛和南沙群岛的整 体名称, 还标出曾母暗沙及大部分岛礁的个体名 称 ${ }^{[4]}$. 1949年中华人民共和国成立初期所出版的地 图基本上沿袭了1948年 “断续线”表示的权属范 围 ${ }^{[11]}$.

本研究发现1948年以后的地图、特别是本研究 新报道的《中华人民共和国新地图》一《全国政 区图》的南海部分，基本沿袭1948年“南海诸岛位置 图”的我国南海疆界范围. 本研究新报道的中华人 民共和国全国政区图南海部分, 更通过红色实线描 绘的与南海U形海疆线范围一致的行政区划线, 将 中国南海划归中南行政区管辖. 可见, 我国南海海 疆国界线自编绘以来就有明确的疆界范围, 主权归 属明确, U形线所包含的疆界范围在历史演变中一 直没有改变.

\section{2 新发现的地图中的U形线的国界线画法}

本文新发现的1951年地图采用连续的国界线 $(\cdot>-—<>-<\cdot)$ 绘制我国南海U形海疆国界线, 与陆地国界线符号 $(\cdot>-<>>-<\cdot)$ 一致. 这不仅 与王颖等人 ${ }^{[14]}$ 研究的官方首次正式公布的 1948 年 《南海诸岛位置图》中我国南海U形疆界线的国界 线符号表示 $(\cdot>-<<>-<\cdot)$ 相同, 而且符合中国 国界线画法相应时期的历史规范: 新中国成立初期 
地图上的中国国界线是以抗日战争前的权威地图, 即“申报地图”的边界画法(一.-.-一)为依据，之后一 律依据中国地图出版社出版的地图国界线画法为准 $(\cdot><<><-<)$, 直到1990年颁布《关于更改公开 版地图上我国国界线画法依据的通知》开始确立现 代的地图国界线画法 $(\cdot|-| \cdot|-|)^{[26]}$. 因此, 该图连续 国界线绘制的我国南海U形线可以更清楚无误地判 定：南海U形线是我国在南海的海疆国界线, 海疆 国界线与陆域国界线是连接在一起的, 是陆域国界 向海的延伸 ${ }^{[14]}$. 该图充分证明U形线是我国南海的 海疆国界线, “U形连续线”符合当时海域疆界线的 绘制方式，具有权威性.

\section{3 新发现的地图中U形线的行政区划线画法}

本研究新发现U形线地图采用红色的实线标识 的行政区划线描绘南海U形线, 与陆地的中南行政 区划线相接(图2(b)), 明确表明1951年中国已经将 $\mathrm{U}$ 形线内海域划归中南行政区辖区范围. 这是对 $U$ 形线及其内海域主权归属中国的关键证明.

\subsection{U形线画法的历史演变}

五幅1951年及以前的南海U形线历史地图(图3) 的对比显示(表1), 从U形线绘制方法的历史演变来 看, 绘制方法是由U形线雉形建立之初的连续线画 法、到断续线画法、再到连续线画法、再到断续线; 而绘制符号的历史演变, 是由最初单纯的线条、到 断续国界线、再到连续国界线、最后演化为断续国 界线. 这与张耀光等人 ${ }^{[11]}$ 的研究一致. 而该新报道 的1951年U形线地图中“连续线”画法绘制的我国南 海U形海疆线，是1912年 ${ }^{[12] 、 1927}$ 年 $^{[11]} 、 1936$ 年 $^{[13]}$ 的中国南海地图都出现的南海的 “连续疆界线”标
示的延续，是对 1948年 ${ }^{[14]}$ 及其后开始逐渐出现的 以“断续线”绘制南海疆界线所划定海域疆界也是 连续的有力证明. 另外, 最新由湖南地图出版社于 2014年4月出版的新编《世界知识地图》 ${ }^{[27]}$ 以地势 图的形式绘制，用断续国界线绘制中国南海U形海 疆线, U形海疆线范围沿袭了1948年《南海诸岛位置 图》范围. 南海海疆国界线用不连接的线段表示, 也是国际上对在水面上划定界限的一种通用的表 达方式 ${ }^{[14,25]}$.

从国际海域疆界线变化看，国际上海洋管辖权 兴起于1945年美国掀起的蓝色圈地运动，这时尚未 形成统一的国际海洋疆界线绘制标准，通常采用与 陆地相同的国界线的方式绘制海域疆界表征海域 主权, 合理且直观有效 ${ }^{[13]}$. 据记载, 美国与西班牙 1898年签订的合约中，就用“实线”表示“岛屿归属 线”, [23], 这说明实线绘制海疆国界线符合历史规范. 当时，国际地图也有以断续线段表示海疆界线, 如: The New Canadian Oxford Atlas中, 在地中海, 意大利与西班牙岛屿的海疆界线、土耳其与希腊之 间的海疆界线，均以断续线段表示 ${ }^{[14]}$. 随着 “断续 国界线”绘制海洋疆界线的出现, “断续线”逐渐成 为国际公认的海域疆界绘制方式，在1958年召开的 第一次联合国海洋法会议上被广泛认可并推广开 来 ${ }^{[13]}$. 因此, “U形断续线”是相应历史时期海疆国 界线的正确描绘.

从中国南海 $\mathrm{U}$ 形线地图的历史变迁来看, 本研 究认为“断续U形国界线”(包括“十一段线”、“九段 线”、“十段线”等)是由初期的“连续U形国界线”(图 3(a)和(d))演化而来. 中国南海“U形断续线”公布后, 得到国际认可, 而且许多国家出版的地图均以此标 绘中国海域疆界 ${ }^{[11]}$ ，并已获得国际许多条约、外交

\section{表 11951 年以前的 $U$ 形海疆国界线历史地图特征和演变}

Table 1 The historical feature and evolution of the U-line on the map before 1951

\begin{tabular}{|c|c|c|c|c|c|}
\hline 地图名称 & 年份 & 绘制形式 & 连续与断续 & 疆界范围 & 出版社 \\
\hline 南海疆界图(图3(a)) ${ }^{[18]}$ & 1936 & 连续实线 & 连续线 & U形线雉形 & 北平建设图书馆 \\
\hline 南海诸岛位置图(图3(b)) ${ }^{[19]}$ & 1948 & 十一段线 & 断续线 & U形线确立, 疆界范围成型 & 商务印书馆 \\
\hline 海南岛与南海诸岛图(图3(c) $)^{[20]}$ & 1948 & 虚线 & 连续线 & 沿袭1948年疆界, U形线连续、完整 & 亚光與地学社 \\
\hline 全国政区图(本文报道)(图3(d) $)^{[17]}$ & 1951 & 国界线、行政区划线 & 连续线 & 完整且连续U形线, 国界范围明确 & 光华与地学社 \\
\hline 中国南海诸岛分布图(图3(e) $)^{[21]}$ & 1951 & 七段线 & 断续线 & 沿袭1948年疆界 & 世界舆地学社 \\
\hline
\end{tabular}


谈判、出版地图和其他官方出版物的批准 ${ }^{[25]}$; 对比 1948年《南海诸岛位置图》、1951年《南海诸岛位 置分布图》和本文报道的1951年《中华民国行政区 域图南海分图》可以看出, 1951年之前就存在“断续 线”画法, 而图3(d)和(e)两个图都是1951年出版的, 一个使用了断续线表示南海海疆国界线, 一个使用 了连续界线, 但都表示海疆国界线. 可见, 1951年 “断续线”描绘国家海域疆界线还没有普及, “断续 线” 和 “连续线”绘制南海U形线在正式出版物中并 存, 都是被官方认可的中国海疆国界线绘制方式. 因此，1951年南海分图中与陆地国界线绘制方式相 同的“连续U形国界线”符合当时的国界线绘制方 式, 具有证明U形海疆线是我国海疆国界线的地图 效力, 更进一步表达我国南海U形海疆国界线的完 整性、连续性和疆界范围的确定性.

\section{5 “南海U形海疆线”适于表征中国南海海疆国 界线}

本研究认为用“南海U形海疆线”表征我国南海 海疆国界线, 具有重要意义. (1) 强调“海疆线”三 个字, 避免单纯以“U形线”称谓的形状来刻画中国 南海疆界线; (2) 能更“形象”表征中国南海海疆国 界线形状, 是对“我国南海的疆界范围呈U形”, ${ }^{[4]}$ 、
“海水是波动的”[14,25]的重要补充; (3) 易于国际、国 内的称谓、表述和记忆; (4) 避免“数字”和“段数”问 题, 能更充分体现南海U形海疆线的完整性; (5) 能 避免潜在历史问题, 具有现实意义, 并为以后的工 作做铺垫. 因此，本研究提议用“U形海疆国界线” 表征中国南海海疆国界线.

\section{4 总结}

(1) 本研究新报道的地图, 用连续U形国界线 绘制我国南海海疆国界线, 并用行政区划线将南海 划归中南行政区管辖范围. 该图收录在1951年4月 由光华与地学社编制的《中华人民共和国新地图》 图册第3 4页的《全国政区图》的《南海分图》中.

(2) 本研究发现的1951年以连续国界线绘制的 中国南海U形线, 是明确且完整的我国南海海疆国 界线; 并且该地图将U形海疆国界线海域划归中南 行政区管辖，主权归属中国.

（3）1947年印制、1948年正式公布的U形海疆国 界线范围沿袭至今; U形连续国界线和U形断续国界 线两种方法都是对我国南海疆界线的描绘, 符合不 同历史时期海上国界线的描绘规则.

(4) 提议用“南海U形海疆线”(SCS U-boundary) 更形象、完整、科学地表征我国南海海疆国界线. 1309.

\section{参考文献}

1 Zhang W B. Consideration given to maps by the international court in settlement of border disputes: The role of the U Shaped Line in resolving the dispute over the Spratly Islands (in Chinese). J Contemp Asia-Pac Stud, 2012, (3): 116-130 [张卫樹. 国际法庭确定领土边 界争端中地图证据分量考—U 形线地图在解决南沙群岛争端中的作用. 当代亚太, 2012, (3): 116-130]

2 Hyd C C. Maps as evidence in international boundary disputes. Am J Int Law, 1933, 27: 311-316

3 Tian H M. Acquiescence in international law: In the perspective of the U-shaped line in the sovereign disputes on Spratly Islands (in Chinese). Chin J Mar Law, 2015, 26: 54-60 [田慧敏. 国际法上的默认一以南沙群岛主权争端中的 U 形线地图为视角. 中国海商法 研究, 2015, 26: 54-60]

4 Han Z H. A Compilation of Historical Data of the South China Sea Islands (in Chinese). Beijing: Orient Publishing House, 1988 [韩振华. 我国南海诸岛史料汇编. 北京: 东方出版社, 1988]

5 Zheng Z H. The admissibility and proof of U-shaped line map of South China Sea (in Chinese). Foreign Affairs Rev, 2013, 30: 30-44 [郑 志华. 中国南海 U 形线地图的可采性与证明力. 外交评论, 2013, 30: 30-44]

6 Ge H L. A research on the international communication of the dotted line in South China Sea (in Chinese). Southeast Asian Stud, 2016, (4): 42-49 [葛红亮. 论南海“断续线”的对外传播. 东南亚研究, 2016, (4): 42-49] 
7 Jiang L, Li L H. South China Sea traditional nine section lines and ocean delimitation (in Chinese). J Ocean Univ China (Soc Sci Ed), 2008, (6): 7-8 [姜丽, 李令华. 南海传统九段线与海洋划界问题. 中国海洋大学学报(社会科学版), 2008, (6): 7-8]

8 Tang M, Ma J S, Wang Y, et al. Spatial demarcation principles of the dotted line in the South China Sea (in Chinese). Acta Geogr Sin, 2016, 71: 914-927 [唐盟，马劲松，王颖，等. 1947 年中国南海断续线精准划定的地形依据. 地理学报, 2016, 71: 914-927]

9 Jia Y. On the law status of Duanxuxian of South China Sea (in Chinese). China's Borderl Hist Geogr Stud, 2005, 15: 112-120 [贾宇. 南 海“断续线”的法律地位. 中国边疆史地研究, 2005, 15: 112-120]

10 Yang C B, Tang L. The role of maps in solving border dispute and China's sovereignty over the Nansha Islands (in Chinese). China Borderl Hist Geogr Stud, 2001, 10: 72-78 [杨翠柏，唐否. 从地图在解决边界争端中的作用看我国对南沙群岛的主权. 中国边疆史地研 究, 2001, 10: 72-78]

11 Zhang Y G, Liu K, Liu G C. The evolvement of the state maritime boundary in South China Sea by maps: China's nine-dotted maritime boundary line in South China Sea (in Chinese). Sci Geogr Sin, 2012, 32: 1033-1040 [张耀光, 刘锴, 刘桂春. 从地图看中国南海海域疆 界线的形成与演进一一国南海九条断续国界线. 地理科学, 2012, 32: 1033-1040]

1214 J. Hu Jinjie and the New Map of the Republic of China (in Chinese). Map, 2005, (3): 88-91 [14 军. 胡晋接与《中华民国地理新图》. 地图, 2005, (3): 88-91]

13 Li J M. The Chinese U-shaped line in the South China Sea: Its background and effectiveness (in Chinese). Southeast Asian Stud, 2011, (1): 41-47 [李金明. 中国南海断续线: 产生的背景及其效用. 东南亚研究, 2011, (1): 41-47]

14 Wang Y, Ge C D, Zou X Q. Evidence of China's sea boundary in the South China Sea (in Chinese)? Acta Oceanol Sin, 2014, 36: 1-11 [王 颖, 葛晨东, 邹欣庆. 论证南海海疆国界线. 海洋学报, 2014, 36: 1-11]

15 Li G Q. Study on the formation history of the territory of China's South China Sea from the evolution of place names (in Chinese). China Borderl Hist Geogr Stud, 2011, (4): 50-59 [李国强. 从地名演变看中国南海疆域的形成历史. 中国边疆史地研究, 2011, (4): 50-59]

16 Huang S Z. The evidence of the South China Sea islands being the traditional Chinese territory (in Chinese). Southeast Cult, 1996, (4): 84-94 [黄盛璋. 南海诸岛历来是中国领土的历史证据. 东南文化, 1996, (4): 84-94]

17 Guanghua and Geological Society. New Map of the People's Republic of China (in Chinese). Beijing: SDX Joint Publishing Company, 1951.3-4 [光华与地学社. 中华人民共和国新地图. 北京：生活·读书·新知三联书店, 1951.3-4]

18 Li J M. South China Sea intermittent line: China's island ownership line (in Chinese). Curr Inf Broch, 2012, (4): 58-59 [李金明. 南海断 续线: 中国的岛屿归属线. 时事资料手册, 2012,(4): 58-59]

19 Fu J J. The Map of the Administrative Region of the Republic of China (in Chinese). Shanghai: The Commercial Press, 1948 [傅角今. 中 华民国行政区域图.上海：商务印书馆, 1948]

20 Yaguang Geography Society Editorial Department. Map of the Provinces of the People's Republic of China (in Chinese). Shanghai: Yaguang Geography Society Publisher, 1952 [亚光與地学社编辑部. 中华人民共和国分省地图. 上海：亚光舆地学出版社, 1952]

21 Tu S C, Wang Z. New World Map (in Chinese). Shanghai: World Society, 1953 [屠思聪, 王振. 新世界地图. 上海：世界与地学社, 1953]

22 Li J M. The current situation of the sovereignty dispute in the South China Sea (in Chinese). Southeast Asian Aff, 2002, (1): 53-65 [李金 明. 南海主权争端的现状. 南洋问题研究, 2002, (1): 53-65]

$23 \mathrm{Xu} \mathrm{Z} \mathrm{L}$. The enlargement of the ocean area of the Republic of China and the intermittent formation of state boundary line on the South Sea (in Chinese). Pacific J, 2010, 18: 92-97 [徐志良. 民国海疆版图演变与南海断续国界线的形成. 太平洋学报, 2010, 18: 92-97]

24 Shen W Z, Xu S A, Li B T. The map of "nine dashed line” on China's South China Sea (in Chinese). Chin Natl Geogr, 2010, (10): 180-182 [沈文周，许森安，李宝田。中国地图上的南海“九段线”. 中国国家地理, 2010, (10): 180-182]

25 Wang Y, Ge C D, Zou X Q. Evidence of China's sea boundary in the South China Sea? Acta Oceanol Sin, 2017, 36: 1-12

26 Lei J H. On the evolution, formation and representation method of Chinese border on map (in Chinese). Bull Surv Mapp, 2011, 30: 52-55 [雷京华. 地图上中国边界的演变、形成及其表示方法探讨. 测绘通报, 2011, 30: 52-55]

27 Hao X G. World's Knowledge Map (in Chinese). Changsha: Hunan Map Publishing House, 2014 [郝晓光. 世界知识地图. 长沙：湖南 地图出版社, 2014] 


\title{
A newly-discovered historical map using both national boundary and administrative line to represent the U-boundary in the South China Sea
}

\author{
Danling Tang ${ }^{1,2^{*}}$, Yupeng Liu ${ }^{1,2}$, Xiaoguang $\mathrm{Hao}^{3}$, Changxia $\mathrm{Wu}^{1,4}$, Sufen Wang ${ }^{1,2}$ \& Yuwei Yin ${ }^{1,2}$ \\ ${ }^{1}$ State Key Laboratory of Tropical Oceanography (LTO), Guangdong Province Key Laboratory of Ocean Remote Sensing (LORS), South China \\ Sea Institute of Oceanology, Chinese Academy of Sciences, Guangzhou 510301, China; \\ ${ }^{2}$ University of Chinese Academy of Sciences, Beijing 100049, China; \\ ${ }^{3}$ Institute of Measurement and Geophysics, Chinese Academy of Sciences, Wuhan 430077, China; \\ ${ }^{4}$ Marine Management, Dalhousie University, Halifax B3H 4R2, Canada \\ *Corresponding author, E-mail: lingzistdl@126.com
}

A New Map of the People's Republic of China was discovered through investigating a large number of historical maps. This map was published in April 1951, both continuous national boundary line and administrative region line were applied in this map to represent China's national U shaped boundary line (U-boundary) in the South China Sea (SCS). It is an important historical material that supports the U-boundary line is the border of China's South China Sea.

This is the first research of this newly-discovered map. In the map, the U-boundary in the SCS (SCS U-boundary) is not only presented by a continuous boundary map symbol $(\cdot>-<>>-<\cdot$ ) (the drawing method of the national boundary line at that time), but also overlay depicted by the red line that represents the administrative dividing line of the Central South Administrative Region of China.

This New Map of the People's Republic of China was edited by the Guanghua and Geosciences Club and was published by SDX Joint Publishing Company. The continuous U-line in this map clearly shows the accurate boundaries of China's border in the SCS. It is an important historical map that clearly proves the U-boundary line is the border of China's territorial sea in the SCS. Moreover, the red solid administrative-line overlaying the U-boundary definitely indicated that the sovereignty of the sea within the U-boundary belonged to China. The regions of the SCS U-boundary include Dongsha Islands, Xisha Islands, Nansha Islands, Zhongsha Islands, Taiwan Island, Beibu Gulf and the Zengmu Reef.

This study compared maps of historical U-line which were published before 1951, and also analyzed the domestic and international maritime situation, and drawing methods of the maritime boundary lines in the history. The results show that "the continuous line" was recognized by the international community in the corresponding historical period, and both the "intermittent (dotted) line" and "the continuous line" are appropriate descriptions and drawing-methods for the sea boundary in historical period. Analysis of six maps, including the historical maps and the latest vertical world map, showed that the territory of U-boundary line inherited the territory of China's SCS in the "South China Sea Island Map" that was officially published and recognized worldwide in 1948.

This study recommends using "the South China Sea U-Shape boundary line" (SCS U-boundary) to describe the border of China's sea in SCS. "SCS U-boundary" not only emphasizes the U shape borderline of China's sea in the SCS, but also can be easily expressed and remembered worldwide. Using "SCS U-boundary" is a better way to avoid problems of "number" and "number of segments", and can further express the certainty of the integrity, continuity and border of the China's seas in the SCS as well.

In summary, the study points out: (1) SCS U-boundary is the border of China's sea in the SCS, and its sovereignty belongs to China; (2) both "continuous U-boundary line" and "intermittent U-boundary line" are internationally recognized to describe sea borders; (3) "SCS U-boundary" is more vividly, accurately, completely and scientifically to characterize China's sea border in the SCS.

\section{South China Sea, continuous border-line, 1951, administrative-line, South China Sea U-boundary}

doi: 10.1360/N972017-00440 